\title{
Decommissioning of small nuclear waste buildings
}

\author{
R. Hedvall ${ }^{1}$, C. Ellmark ${ }^{2}$ and P. Stocker ${ }^{2}$ \\ ${ }^{1}$ AB SVAFO, 61182 Nyköping, Sweden \\ 2 Studsvik Nuclear AB, 61182 Nyköping, Sweden
}

\begin{abstract}
A small-scale decommissioning concept was applied with staff from an earlier project with strong knowledge of radiation protection, minimized radiation doses and environmental pollution. The project was therefore initiated with less than 10 people involved using standard handheld equipment. The aim of the decommissioning project was to set free as much material as possible, i.e. remove waste from the regulatory control regime and also free the remaining structures and buildings for conventional demolition and subsequent reuse of the property. A final decommissioning plan was drafted together with a safety assessment covering the planned activities and abnormal events that may occur during decommissioning. Applications and contacts were made with five different authorities to obtain permits pursuant to national safety standards and requirements, including the areas of safety (Swedish Nuclear Power Inspectorate), radiation protection (Swedish Radiation Protection Institute), environmental protection (County Administrative Board), construction (Swedish Work Environment Authority) and building demolition (Municipality of Nyköping). Sufficient funds were available for decommissioning. Complete decommissioning will be concluded at the end of 2008 when all waste is taken care of. This is the fourth in a series of important decommissioning projects in Studsvik since the 1980s.
\end{abstract}

\section{INTRODUCTION}

Contamination measurements in empty buildings were performed well in advance (2003) as a major part of the planning of the decommissioning and immediate dismantling [1] of four simple Aluminiumsheds (AS) at the end of their useful life and a delayed dismantling of an evaporation plant (ID) that is no longer required. They were all built in the beginning of the 1960s, the AS for the storage of nuclear waste and the ID to treat liquid waste from two nuclear reactors (R2 and R2-0). One of the sheds was also used for a small incinerator for burnable, low-activity nuclear waste in the 1960s. Previous experience was obtained from the decommissioning and recent demolition of a nuclear laboratory [2].

AB SVAFO is a nuclear waste technology and decommissioning company based in Sweden in the scenic surroundings of Studsvik on the Baltic coast in the county of Södermanland, $80 \mathrm{~km}$ south of Stockholm. Studsvik AB acquired SVAFO in 2003 from the Swedish nuclear power industry. The company was created in 1992 by Sydsvenska Värmekraft AB, Vattenfall AB, Forsmarks Kraftgrupp $\mathrm{AB}$ and Oskarshamns Kraftgrupp $\mathrm{AB}$ as a consequence of the Act on the Financing of the Management of Certain Radioactive Waste etc. [3].

AB SVAFO's main business is to take care of formerly state-owned spent nuclear waste at the site, including small amounts of nuclear fuel and some nuclear buildings. Some buildings will now be decommissioned.

\section{BUILDINGS}

The floors of AS, $150 \mathrm{~m}^{2}$ each, consist of concrete in one of the buildings and asphalt in the three others. In 2003, all waste was removed except 3982 concrete blocks, totalling 64 tonnes. Loose contamination was found on only 82 blocks thanks to vacuum cleaning of the blocks. But because of the humid air in the 
unheated sheds only $35 \%$ of the blocks were free from internal contamination. A probable explanation to this is use of water when cleaning up in 1995.

The floors were surface grinded but kept after the project as a basis for the storage of future waste containers. A total of 1,600 smear samples were taken at an early stage. Scintillation instruments were used for all surfaces and solid state detectors for gamma in situ measurements confirmed the levels for free release. Contamination was above $100 \mathrm{kBq} / \mathrm{m}^{2}$ beta/gamma in only one of the sheds.

ID was built in 1963-1964 and was ready for testing in the autumn of 1964. The facility was used for the treatment of liquid waste (category 1-3). Category 1 is for highly radioactive liquid, 2 from reactor water in case of an emergency and 3 is for medium radioactive solutions. The waste originated from the R2-reactor loops, laboratories and from decontamination. Capacity was $0.75 \mathrm{~m}^{3} / \mathrm{h}$. During a test period in 1964 and 1965 uranium was used (uranylnitrate solution (100-150 g/l)).

ID consists of two floors. On the ground floor is a control and operating room. Process equipment is located in the cellar. The main components are in the evaporator cell with $1 \mathrm{~m}$ thick concrete walls. The system is located next to the radioactive waste water channel and a separate steam-heated water channel for evaporation concentrate.

ID has never been in use but was tested in a trial and is therefore contaminated with Co-60, Cs-137, U-238, H-3 and Am-241. Almost 500 smear tests were taken at an early stage before 2007. Scintillation instruments were used for all surfaces and gamma in situ measurements were performed as a confirmation at the end. Valves in the active ventilation system were contaminated up to $3000 \mathrm{kBq} / \mathrm{m}^{2}$ gamma/beta (less than $0.3 \mathrm{mSv} / \mathrm{h}$ ) and the pump pit up to $1000 \mathrm{kBq} / \mathrm{m}^{2}$. Other parts had less than $100 \mathrm{kBq} / \mathrm{m}^{2}$.

\section{WASTE}

Metals for melting at Studsvik and a probable release for subsequent reuse and recycling of materials were placed in 8 standard and 8 small containers. Most of this was Aluminium from AS. Less than 100 200-L drums containing mainly soil and asphalt will later be separated into low level waste and/or waste for a municipal dump. Small amounts of asbestos materials were taken care of according to standard methods for non-radiological hazardous materials. One container with low activity waste were packed for a coming incineration.

\section{INSTRUMENTATION}

Regulations on the removal of nuclear waste from normal operating activities for deposit in municipal dumps from nuclear installations have $40 \mathrm{kBq} / \mathrm{m}^{2}$ for beta and gamma radiation and $4 \mathrm{kBq} / \mathrm{m}^{2}$ for alpha radiation as a limit for surface contamination and $5 \mathrm{kBq} / \mathrm{kg}(0.5 \mathrm{kBq} / \mathrm{kg}$ for alpha) for specific activity. Free release (clearance) of tools and other equipment is allowed if less than $0.5 \mathrm{kBq} / \mathrm{kg}(0.1 \mathrm{kBq} / \mathrm{kg})$. Total disposal activity to a municipal dump for all waste from Studsvik is limited to $1 \mathrm{GBq} / \mathrm{year}$.

The choice of instrumentation affects efficiency. Using handheld instruments is time-consuming and demands a high degree of patience from the staff. It is also clear that detectors with a large detector area are more efficient than those with a smaller area, but are heavier and more difficult to handle. The handheld instruments used were scintillators with a background level about $15 \mathrm{cps}$ (beta). This was the working level for permitted indoor decontamination. Outside AS on the surface of the asphalt, the working level was $100 \mathrm{cps}$ (beta). For the practical decontamination limit of loose materials, the above limits were divided by 10 .

In-situ gamma spectrometry was a good complement in the project and during pre-studies. The gamma in-situ spectroscopy had several benefits:

- Discovery of sub-surface contamination not detectable with handheld equipment.

- An efficient way of specifying the total amount of activity left behind (within the free release conditions). 
- It is important to have a statistical approach to the measurement programme and the different scenarios in the measurement plan.

No internal or external radiation doses were received during the half-year decommissioning project.

\section{FINANCES}

A fund was established in 1989 to provide and ensure adequate financial resources for safe and timely decommissioning. A cost estimate for all parts of the decommissioning has been reviewed during the years.

Since 1989 a special fee has been levied on the nuclear power utilities according to the aforementioned legislative act (also called the Studsvik Act) [3]. This fee is intended to cover expenses to finance the treatment of historic waste, created before 1991 by Studsvik, at that time a company owned by the state (AB Atomenergi), to develop knowledge for the Swedish nuclear programme. This also includes Ågesta nuclear power reactor and the former uranium mine in Ranstad. According to the estimates SEK $1700 \mathrm{M}$ will be needed up to the year 2045 to meet these expenses. The special fee used to be 0.0015 SEK per produced kilowatt-hour for the nuclear power industries but is now $0.003 \mathrm{SEK}$. The fee is reassessed each year based on calculations by AB SVAFO and a proposal by the Swedish Nuclear Power Inspectorate (SKI). SKI submits a request to the board of the Swedish Nuclear Waste Fund (Kärnavfallsfonden) for disbursements from the fund bureau of the Legal, Financial and Administrative Services Agency (Kammarkollegiet) to AB SVAFO.

An update on decommissioning costs was performed in 2006 taking radiological conditions into account. It was based on cost estimates for preparation work, required documents, work schedules, transportation of waste, security and supplementary work on the basis of the experience accumulated during the decommissioning of German nuclear plants. The cost estimate was SEK $8 \mathrm{M}$ not including the cost for conventional demolition of the buildings. This figure was adjusted to SEK 6 M in 2007. Initial planning was based on three employees and a project manager during a 27 week period, but was later changed to five employees due to the delay of the start of the project.

\begin{tabular}{|l}
$\square$ Equipment \\
$\square$ Decommissioning \\
plans \\
$\square$ Pre study \\
$\square$ Waste registration, \\
administration \\
$\square$ Project manager \\
$\square$ Group manager \\
$\square$ Workers \\
$\square$ Analyses
\end{tabular}

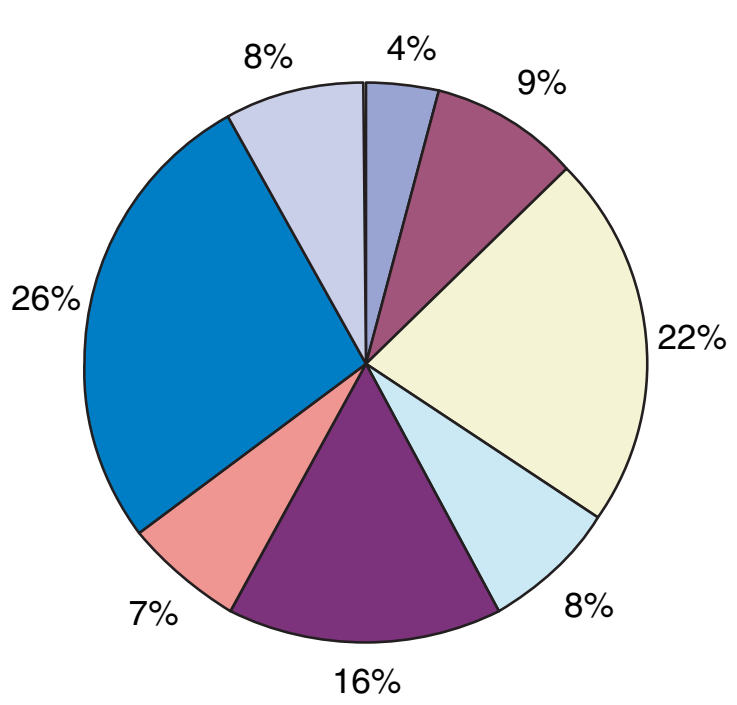

Figure 1. Decommissioning costs after more than half of the project. 
Now, with more than half of the project funding having been spent, the AS have been dismantled in preparation of upcoming recasting of metals at the site and ID has been decontaminated and is ready for conventional demolition.

\section{RESULTS AND CONCLUSIONS}

The AS were disassembled between October and December 2007 in a safe and environmentally acceptable manner. The Aluminium sheeting and wall and ceiling steel construction will be recast at Studsvik. The final radiation survey is not yet complete. More work also remain with sample analysis, waste treatment and a final application for free release.

\subsection{No exposure to radiation or environmental effects were found}

To reduce the risk of dust dispersion, the following measures were undertaken:

- Clothing and shoes were changed at a designated step-over

- A plastic tent with negative air pressure (from construction fans) was used when contaminated surfaces were ground

- Standard equipment such as sabre saws, pneumatic drills, vacuum cleaners with absolute filters and grinding machines with point vacuum extraction were used.

- After grinding and chiselling, the tent and personnel were vacuumed. The surfaces were wiped with alcohol and smear tests were taken.

No radiation exposure of personnel was measured. No contamination of the surroundings was due to the decommissioning.

\subsection{Conclusions and lessons learned}

From this project and prior experiences from other projects [2] some conclusions can be drawn:

- Obtain all permits and requirements well in advance - it takes longer than you think.

- Obtain a group with well-known personnel that have been working together before for the entire project. For a project larger than this, project management assistant would have made follow-up more efficient. Experts in instrumentation and statistics are also important. Also important is knowledge about practical decisions that would make the project more efficient in terms of time. Interviews and historical facts are important when choosing which nuclides are of most interest for measurements (but be critic).

- Be sure all authoritative requirements are followed, like setting up a work environment plan at the entrance to the site and placing a fence around the worksite.

- Check all individual radiation exposures before project start and do whole body measurements both before and after the project. Urine samples should be taken if alpha contamination is a risk.

- Do not use water for decontamination - contamination can be forced into the material.

- Calculate for unwanted and "not what you expected" situations in the time schedule.

- Be aware of contaminations and radiation sources outside the actual area. They might have to be moved.

- Calculate and order bins and containers for waste storage well in advance. Stay informed of the updated amount of waste and keep it in locked storage.

- Analyze what instrumentation you need and calibrate it in advance. Notice that detectors with a large detector area are more efficient than those with a smaller area, but are heavier and more difficult to handle. Gamma in situ measurements are an effective confirmation at the end.

- Order the equipment you need in time. Have one person responsible for materials.

- Establish an updated plan for the last few weeks of work to motivate the team. Place this plan in a location very visible to the staff and update it daily. 


\section{References}

[1] International Atomic Energy Agency, Decommissioning of Facilities Using Radioactive Material, IAEA Safety Requirements No. WS-R-5, IAEA, Vienna, 2006

[2] Hedvall, R., H. Stridsman, H, R. Berg and B. Johnsson, Project Evaluation of the Decommissioning of a Laboratory Plant in Studsvik, Proceedings, WM '06 Conference, Tucson, 2006

[3] SFS, Svensk Författningssamling, Lag (1988:1597) om finansiering av hanteringen av visst radioaktivt avfall $\mathrm{m}$. $\mathrm{m}$. 
